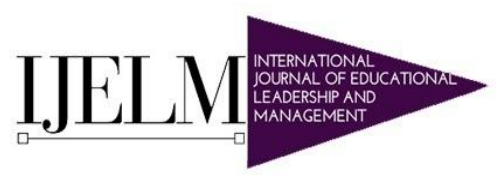

Hipatia Press

www.hipatiapress.com

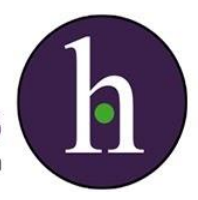

Instructions for authors, subscriptions and further details:

http://ijelm.hipatiapress.com

\title{
The Phenomenon of Leading without Guidebook: Educational Leadership Practices of Philippine School Principals in Virulent COVID-19 Times
}

Michael B. Cahapay ${ }^{1}$

1) Mindanao State University, General Santos City, Philippines

Date of publication: January $16^{\text {th }}, 2022$

Edition period: January 2021 - July 2021

To cite this article: Cahapay, M. B. (2022). The Phenomenon of Leading without Guidebook: Educational Leadership Practices of Philippine School Principals in Virulent COVID-19 Times. International Journal of Educational Leadership and Management. 10 (1), doi: 10.17583/ijelm.2022.7666

To link this article: http://dx.doi.org/10.17583/ijelm.2022.7666

PLEASE SCROLL DOWN FOR ARTICLE

The terms and conditions of use are related to the Open Journal System and to Creative Commons Attribution License (CCAL). 


\title{
The Phenomenon of Leading without Guidebook: Educational Leadership Practices of Philippine School Principals in Virulent COVID-19 Times
}

\author{
Michael B. Cahapay \\ Mindanao State University, General Santos City \\ Philippines
}

\begin{abstract}
The school principals play a pivotal role in leading educational institutions. Their lived experience as educational leaders in the context of a virulent crisis, however, is largely unexplored. This paper sought to discover the essence of educational leadership practices of school principals in the context of the current COVID-19 crisis. Following phenomenology as a research design, the researcher explored the world of six Filipino school principals through interview procedures. The analysis method developed by Colaizzi (1978) was used. The results revealed six emerging themes of educational leadership practices during a crisis as follows: 1.) navigating the crisis with adaptive leadership; 2.) cultivating practices in crisis management; 3.) managing through the machine; 4.) freezing the standards and patterns; 5.) promoting inclusivity in the new normal; and 6.) caring first for what is essential. These themes form the basis of the description and structure of the phenomenon offered at the end of the paper. Considering the present scarcity of knowledge on how school principals respond in times of crisis, this paper provides insights into educational leadership practices within the context of the COVID-19 situation.
\end{abstract}

Keywords: educational leadership practices, lived experience, school principal, COVID-19, Philippines

2022 HipatiaPress

ISSN: 2014-9018

DOI: $10.17583 /$ ijelm.2022.7666 


\title{
El fenómeno de liderar sin guía: prácticas de liderazgo educativo de directores de escuelas filipinas en tiempos virulentos de COVID-19
}

\author{
Michael B. Cahapay \\ Mindanao State University, General Santos City \\ Philippines
}

\section{Resumen}

Los directores de escuela desempeñan un papel fundamental en las principales instituciones educativas. Su experiencia vivida como líderes educativos en el contexto de una crisis virulenta, sin embargo, está en gran parte inexplorada. Este trabajo buscó descubrir la esencia de las prácticas de liderazgo educativo de los directores de escuela en el contexto de la actual crisis del COVID-19. Siguiendo la fenomenología como diseño de investigación, el investigador exploró el mundo de seis directores de escuela filipinos a través de procedimientos de entrevistas. Se utilizó el método de análisis desarrollado por Colaizzi (1978). Los resultados revelós seis temas emergentes de prácticas de liderazgo educativo durante una crisis de la siguiente manera: 1.) navegar la crisis con liderazgo adaptativo; 2.) cultivar prácticas en la gestión de crisis; 3.) gestión a través de la máquina; 4.) congelar los estándares y patrones; 5.) promover la inclusión en la nueva normalidad; y 6.) cuidar primero de lo esencial. Estos temas forman la base de la descripción y estructura del fenómeno que se ofrece al final del artículo. Teniendo en cuenta la escasez actual de conocimiento sobre cómo responden los directores de escuela en tiempos de crisis, este documento proporciona información sobre las prácticas de liderazgo educativo en el contexto de la situación de COVID-19.

Palabras clave: prácticas de liderazgo educativo, experiencia vivida, director escolar, COVID-19, Filipinas 
Cahapay. The Phenomenon of Leading without Guidebook: Educational Leadership

Practices of Philippine School Principals in Virulent COVID-19 Times

O

ince the spread of COVID-19 across countries in the world, it has changed the educational sector in unimaginable ways. The current situation is preventing the educational sector from performing its primary function to educate children. With recovery plans formulated to get schools on their feet, it is the school principals who are in a challenging position to lead the course of education amid the crisis. As Harris and Jones (2020) expressed, school principals cannot just go back to the educational leadership practices they apply in the former period of certainty, stillness, and predictability. Being a leader in perturbing periods means being able to chart different water and move in a new direction amid ambiguities.

The UNESCO (2020), together with the Teacher Task Force and the International Labor Organization, has designed a framework to assist school principals in the safe return to school. Acknowledging the significant role of the school principals, it offered seven key dimensions to guide them in this daunting time. These dimensions include social dialog and communication; safety and health; psychological and social wellbeing; teacher preparation and learning; teacher deployment, rights, and condition; financial resources and investments; and monitoring and evaluation.

The Philippine Department of Education (2020) also acknowledged the important position of the school principals in the continuity of education amid the COVID-19 crisis. It asserted its obligation to giving professional development to school principals. The school principals were trained to carry out the adoption of an array of learning delivery prototypes based on their preparedness, resources, and plans. They were given an opportunity to be familiar with the range of learning delivery prototypes they can employ depending on the capacity and situation of the community they are located. They were capacitated to lead the continuity of education amid the crisis.

However, despite such efforts to assist school principals lead education during difficult times, educational leadership at present is fraught with many challenges. School principals often encounter problems such as budget shortage and social divides (Kruse et al., 2020) to which they may not necessarily know the best solution. As Harris (2020) said, there is no neat guidebook for educational leadership in such difficult times. The educational 
leadership practices based on lived experience in the context of crisis is an unexplored territory that needs to be written as a part of the present history.

Euber (2020) expressed that, through research in the form of written reports and oral histories, scholars especially in higher education are trying to record the lived experience of people to understand the COVID-19 crisis. He noted, however, that in overly disruptive moments like the current global crisis, it is difficult to draw research through the lived experience. With that challenge, The Lancet (2020) stressed that sustainable research must be encouraged because they are important, not only to the victory of COVID-19 solutions but also to the conditions of all communities globally.

The lived experience of students, teachers, and parents amid the COVID19 crisis have been attempted to be recorded by some scholars (e.g. see Cahapay, 2020; Henaku, 2020; Rahiem, 2020; Joshi et al., 2020; Karakaya et al., 2020; Said et al., 2020; Cahapay, 2021). A few conceptual papers have also been written by other scholars from the perspective of the school principals and their educational leadership practices (Kaul et al., 2020; Kruse et al., 2020; Marshall et al., 2020). Studies closely exploring the lived experience of the school principals and their practices amid a virulent crisis, however, are rarely represented in the current body of research.

Accounting for the lived experience of the school principals amid the current crisis is a significant scholarly task in completely understanding the essence of educational leadership practices in these disruptive moments. It will offer theoretical and practical insights for possible attention in the expansion of the field of educational leadership in times of crisis. Considering these circumstances, this paper is designed as phenomenological research that aims to uncover the essence of educational leadership practices of school principals in the context of the present COVID-19 situation.

\section{Methods}

Guided by the research goal, this section details the methods employed in this study. It includes the design, participants, setting, instrument, data collection, and data analysis. 
Cahapay. The Phenomenon of Leading without Guidebook: Educational Leadership

Practices of Philippine School Principals in Virulent COVID-19 Times

\section{Design}

A phenomenological approach to qualitative research was employed to achieve the goal of this paper. It is an appropriate research design to address the interest of this research that revolves around the essence of a phenomenon (Lin, 2013) which in this study is the educational leadership practices of the school principals amid the COVID-19 crisis. Cresewell (2007) further stated that a phenomenological approach allows for an exhaustive manner of inquiring into how the participants experience the phenomenon through the lens of their individual experience.

\section{Participants}

As phenomenological research, this paper employed a criterion sampling technique, in which the participants are selected based on a defined criterion (Patton, 2001). The primary criterion in this study is the experience of the target participants with the phenomenon under investigation. Moreover, in phenomenological research, the participants who have a common experience of the phenomenon but differ in some respects are selected (Moser, 2018). Thus, for this study, the researcher selected Filipino K to 12 school principals with varying characteristics in terms of age, gender, school location, and leadership experience. Table 1 shows these characteristics.

Table 1. Participant characteristics

\begin{tabular}{|c|c|c|c|c|}
\hline Participant & Age & Gender & Location & Experience \\
\hline 1 & 35 & Male & Urban & 4 years \\
\hline 2 & 56 & Female & Rural & 12 years \\
\hline 3 & 60 & Male & Rural & 10 years \\
\hline 4 & 32 & Female & Rural & 2 years \\
\hline 5 & 38 & Female & Rural & 6 years \\
\hline 6 & 48 & Female & Urban & 8 years \\
\hline
\end{tabular}


Furthermore, Morse (1996) recommended a modest guideline for the sample in phenomenology, suggesting at least six participants. As much as this research wanted to involve a larger sample size, however, the COVID19 crisis posed constraints. At the end of the sampling process, this study was able to enlist a total of six school principals as participants, which is still considered adequate for the purpose of this research.

\section{Setting}

This study was conducted in Mindanao, Philippines amid the global COVID-19 crisis. Fink (2002) indicated that a crisis occurs at three stages: the prodromal stage in which an issue is emerging; a crisis stage in which the issue has completely surfaced, and the resolution stage in which the issue is no longer a concern. This study appears to be situated in the middle of the crisis stage. It was conducted between December 2020 and January 2021 when school leaders are observed to have been constantly grappling with the deleterious impacts of the COVID-19 crisis.

\section{Instrument}

The researcher designed an interview guide that consists of four sections: an introduction, short survey of participant information, list of questions, and conclusion. Specifically, the section for the list of questions contained questions to uncover the essence of educational leadership practices from the perspectives of school principals in the context of the current crisis. The central question is: What does it mean to lead a school during disruptive times of the COVID-19 crisis? It served as the basis for the subsequent questions. These questions were content validated by two education professors and a $\mathrm{K}$ to 12 school principal to ensure their suitability. 
Cahapay. The Phenomenon of Leading without Guidebook: Educational Leadership

Practices of Philippine School Principals in Virulent COVID-19 Times

\section{Data collection}

Online modalities are increasingly used for collecting qualitative data. One of these online modalities is online interviews. With online interviews, data can be collected synchronously or asynchronously, with text messages, video calls, or immersive worlds (Salmons, 2015). The online interview procedures for this study occurred in three stages.

In the first stage, the researcher introduced the purpose and procedure of the research to the potential participants. The ethical considerations were also discussed, underscoring that involvement in the study is completely anonymous, confidential, and voluntary. It was expressed to the participants that potential disadvantages in the research process were minimal, but they were assured that, if at any time the process becomes agitating, they may stop. After securing their consent, the participants received the interview guide containing the questions either through Messenger or Gmail. Most of them answered offline. Then, the initial data were gathered and examined.

In the second stage, the researcher arranged a time that is convenient with selected participants for a synchronous interview. It was conducted as a way to gather further information on the answers of the participants that need probes. The participants were asked to explain based on their initial responses. After that, additional data were gathered. Then, all the data generated from the two stages were organized by the researcher in a master transcript.

In the third stage, the researcher arranged again a time that is convenient for some participants for interview. This occurred after the data have been analyzed. The purpose of this interview is to gather evidence of the validity of the interpretation of the researcher. Given the copy of the results, the researcher asked the participants if the fundamental structure statement captures their experience. Their reviews were considered in the final stage of data analysis and presentation. 


\section{Data Analysis}

Knowing an array of data analysis methods in phenomenological studies, the researcher particularly selected the method proposed by Colaizzi (1978). This method presents a robust qualitative data analysis technique that warrants the validity of the results. It provides the researcher a structured technique to uncover themes and their interlacing relationships (Wirihana et al., 2018).

Specifically, this method of Colaizzi (1978) consists of seven developmental steps as follows: 1.) acquiring a sense of each transcript; 2.) extracting significant statements; 3.) formulating meanings; 4.) organizing the meanings into themes; 5.) describing the phenomenon; 6.) describing the fundamental structure; and 7.) returning to the participants (Sanders, 2014). Overall, these seven steps were adopted by the researcher because it presents a cogent process through which the fundamental structure of the educational leadership practices of school principals in the context of the COVID-19 crisis can be explored.

\section{Result and Discussion}

This section presents the results drawn for this study. They are developmentally organized and discussed following the method for data analysis in phenomenology as prescribed by Colaizzi (1978). Each section is accompanied by descriptions so that the presentation of the results will be more logically comprehensible to the readers.

\section{Extraction of the statements}

The researcher immersed first with the data by constantly reading through all the participant accounts page by page in the master transcript. This process identified all statements in the accounts that are of significance to the phenomenon (Morrow et al., 2015), which in this case is the educational leadership practices amid the COVID-19 crisis. Table 2 presents the sample of these statements. 
Cahapay. The Phenomenon of Leading without Guidebook: Educational Leadership

Practices of Philippine School Principals in Virulent COVID-19 Times

Table 2. Sample statements extracted from the transcript

\begin{tabular}{|c|c|l|}
\hline Page & Line & \multicolumn{1}{|c|}{ Statement } \\
\hline 1 & $021-022$ & $\begin{array}{l}\text { I manage concerns and issues nowadays mostly on the } \\
\text { implementation of the basic education learning continuity } \\
\text { plan at the school level specifically the modular distance } \\
\text { learning modality. }\end{array}$ \\
\hline 3 & $051-052$ & $\begin{array}{l}\text { My use of digital tools in school management has increased } \\
\text { dramatically. I do attendance management, data gathering, } \\
\text { reporting, feedback, and communication online. }\end{array}$ \\
\hline 5 & $097-099$ & $\begin{array}{l}\text { The impact of the crisis exposed the vulnerability of the mind. } \\
\text { I am concerned most of my teachers - their difficulties, } \\
\text { problems, and anxieties because of their past experiences. }\end{array}$ \\
\hline 7 & $143-145$ & $\begin{array}{l}\text { I have learned better online ways and means to present a } \\
\text { school report and communicate with those at the higher } \\
\text { authorities. }\end{array}$ \\
\hline 11 & $190-192$ & $\begin{array}{l}\text { Ialso encourage teachers to really give their best commitment } \\
\text { to deliver instruction to the most important client in the } \\
\text { department in the new normal. }\end{array}$ \\
\hline 13 & $275-277$ & $\begin{array}{l}\text { When conducting meetings, I wanted to have a 100\% } \\
\text { attendance from my teachers. I needed to consider others due } \\
\text { to low internet connectivity and black outs. }\end{array}$ \\
\hline $\begin{array}{l}\text { We create a team by village. There are assigned volunteers to } \\
\text { help those learners and parents who are not capable to answer } \\
\text { or follow the self-learning modules. }\end{array}$ \\
\hline $\begin{array}{l}\text { Those learners whose parents who are jobless due to the } \\
\text { pandemic are vulnerable. But we encourage them to enroll } \\
\text { because there are no miscellaneous fees. }\end{array}$ \\
\hline $\begin{array}{l}\text { As an implementing school of indigenous people education, } \\
\text { blending with the existing culture and practices is a very } \\
\text { challenging art of leadership to ensure the sustainability of } \\
\text { partnership. }\end{array}$ \\
\hline $15-364-310$
\end{tabular}




\begin{tabular}{|l|l|l|}
\hline 19 & $398-400$ & $\begin{array}{l}\text { Teachers are requested to deliver the modules right at the } \\
\text { doorsteps of the children. Parents are also given assistance by } \\
\text { the teachers through call and messages. }\end{array}$ \\
\hline
\end{tabular}

The initial process of the transcript review and then data extraction identified a total of 56 significant statements. The result of this procedure is represented by 10 samples as displayed above. They are an individual extrapolation from the master transcript. It should be noted that no deliberate action was exerted to group them or sequence them. The researcher only presented how the school principals perceived their experience as educational leaders amid the COVID-19 crisis.

\section{Formulation of the meanings}

The researcher then identified the meanings relevant to the phenomenon that arise from the examination of the significant statements. As advised by Ashworth and Hagan (1993), it is essential in this stage to acknowledge any subjective assumptions to avoid the tendency to misinterpret. The researcher observed this caution. Table 3 presents the sample of these statements and their formulated meanings.

Table 3. Sample statements and their formulated meanings

\begin{tabular}{|c|lr|}
\hline Statement & \multicolumn{2}{|c|}{ Meaning } \\
\hline $\begin{array}{l}\text { We scheduled a meeting with the teachers and } \\
\text { parents to express the issue on which learning } \\
\text { modality, and we have come up with } \\
\text { agreement about it. }\end{array}$ & $\begin{array}{l}\text { The teachers and parents are } \\
\text { consulted and heard on } \\
\text { important issues. }\end{array}$ \\
\hline $\begin{array}{l}\text { We create a team by village. There are assigned } \\
\text { volunteers to help those learners and parents } \\
\text { who are not capable to follow the self-learning } \\
\text { modules. }\end{array}$ & $\begin{array}{l}\text { The school principal and } \\
\text { teachers collaborate in } \\
\text { accomplishing tasks. }\end{array}$ \\
\hline
\end{tabular}


Cahapay. The Phenomenon of Leading without Guidebook: Educational Leadership

Practices of Philippine School Principals in Virulent COVID-19 Times

\begin{tabular}{|c|c|}
\hline $\begin{array}{l}\text { I also encourage teachers to really give their } \\
\text { best commitment to deliver instruction to the } \\
\text { most important client in the department in the } \\
\text { new normal. }\end{array}$ & $\begin{array}{l}\text { The school principal motivates } \\
\text { the teachers to do their best in } \\
\text { their duties. }\end{array}$ \\
\hline $\begin{array}{l}\text { I manage concerns and issues nowadays } \\
\text { mostly on the implementation of the basic } \\
\text { education learning continuity plan at the school } \\
\text { level specifically the modular distance learning } \\
\text { modality. }\end{array}$ & $\begin{array}{l}\text { The school principal ensures } \\
\text { that a learning continuity plan is } \\
\text { carried out amid the crisis. }\end{array}$ \\
\hline $\begin{array}{l}\text { There is a provision of hand sanitation and } \\
\text { advocacy materials. There are items in the } \\
\text { monthly cash program intended for this. }\end{array}$ & $\begin{array}{l}\text { Materials related to crisis safety } \\
\text { are allocated budget. }\end{array}$ \\
\hline $\begin{array}{l}\text { I try hard to balance the timeliness of target } \\
\text { outputs and the increasing virtual school } \\
\text { leadership auxiliary extended tasks which are } \\
\text { not identified in the national school calendar } \\
\text { year of activities. }\end{array}$ & $\begin{array}{l}\text { The school principal balances } \\
\text { new demands and tasks arising } \\
\text { from the crisis. }\end{array}$ \\
\hline $\begin{array}{l}\text { We created group chats, and we have a meeting } \\
\text { or conference via Google and Zoom. With } \\
\text { these platforms, we are able to meet the tasks. }\end{array}$ & $\begin{array}{l}\text { School planning activities are } \\
\text { conducted and accomplished } \\
\text { online. }\end{array}$ \\
\hline $\begin{array}{l}\text { My use of digital tools in school management } \\
\text { has increased dramatically. I do attendance } \\
\text { management, data gathering, reporting, } \\
\text { feedback, and communication online. }\end{array}$ & $\begin{array}{l}\text { Digital tools are used to perform } \\
\text { management functions. }\end{array}$ \\
\hline $\begin{array}{l}\text { I have learned better online ways and means to } \\
\text { present a school report and communicate with } \\
\text { those at the higher authorities. }\end{array}$ & $\begin{array}{lrr}\begin{array}{l}\text { School monitoring } \\
\text { evaluation activities } \\
\text { conducted online. }\end{array} & \text { are } \\
\end{array}$ \\
\hline $\begin{array}{l}\text { There are policies that were being considered } \\
\text { because easing its implementation will make } \\
\text { the process efficient in this time. For example, } \\
\text { the protocol in financial flow. }\end{array}$ & $\begin{array}{l}\text { The processes in the } \\
\text { implementation of policies are } \\
\text { modified. }\end{array}$ \\
\hline
\end{tabular}




\begin{tabular}{|l|l|}
\hline $\begin{array}{l}\text { I would allow some of my teachers to go home } \\
\text { early, especially those of them who reside far } \\
\text { and have to commute to go home. }\end{array}$ & $\begin{array}{l}\text { Flexibility of work hours for } \\
\text { teachers is observed. }\end{array}$ \\
\hline $\begin{array}{l}\text { I meet my teachers and encourage them to } \\
\text { adjust their grading standards. I told them that } \\
\text { as long as students submit anything, give them } \\
\text { a passing mark. }\end{array}$ & $\begin{array}{l}\text { The teachers are encouraged to } \\
\text { adjust their grading practices. }\end{array}$ \\
\hline $\begin{array}{l}\text { Those learners whose parents who are jobless } \\
\text { due to the pandemic are vulnerable. But we } \\
\text { encourage them to enroll because there are no } \\
\text { miscellaneous fees. }\end{array}$ & $\begin{array}{l}\text { Children belonging to poor } \\
\text { families are encouraged to } \\
\text { continue. }\end{array}$ \\
\hline $\begin{array}{l}\text { I have asked the teachers to track the learners } \\
\text { who find difficulty in reading and create a plan } \\
\text { to conduct individual reading sessions. }\end{array}$ & $\begin{array}{l}\text { Children with difficulties in } \\
\text { learning are assisted to learn. }\end{array}$ \\
\hline $\begin{array}{l}\text { Some modules of the learners especially those } \\
\text { located in the far-flung sitios are being } \\
\text { neglected. But with the dedication of our } \\
\text { teachers, at least } 80 \% \text { of the learners' modules } \\
\text { are collected and monitored. }\end{array}$ & $\begin{array}{l}\text { Children from remote areas are } \\
\text { reached out by teachers. }\end{array}$ \\
\hline $\begin{array}{l}\text { The impact of the crisis exposed the } \\
\text { vulnerability of the mind. I am concerned most } \\
\text { of my teachers - their difficulties, problems, } \\
\text { and anxieties because of their past experiences. }\end{array}$ & $\begin{array}{l}\text { Guarding mental health is a } \\
\text { primary concern of the school } \\
\text { principal. }\end{array}$ \\
\hline $\begin{array}{l}\text { Ensuring that everyone is safe and sound in the } \\
\text { delivery of basic education is my common } \\
\text { concern for my teachers and our learners. }\end{array}$ & $\begin{array}{l}\text { The school principal is } \\
\text { concerned about the safety of } \\
\text { teachers and learners. }\end{array}$ \\
\hline $\begin{array}{l}\text { I realized that because of the crisis, the most } \\
\text { important thing at the moment is life. Our goal } \\
\text { should be to get out alive of this situation. }\end{array}$ & $\begin{array}{l}\text { The school principal recognizes } \\
\text { that life should be the priority } \\
\text { during this crisis. }\end{array}$ \\
\hline
\end{tabular}

This stage ascribed meanings to all the 56 statements. The result of this process is represented by 18 samples as shown above. The researcher constantly compared the initially formulated meanings with the original statements to ensure appropriateness until the final formulated meanings were 
Cahapay. The Phenomenon of Leading without Guidebook: Educational Leadership

Practices of Philippine School Principals in Virulent COVID-19 Times

generated. These meanings underlie the phenomenon of educational leadership practices amid the COVID-19 crisis.

\section{Organization of the themes}

Once the meanings were formulated for all the statements, the researcher organized the formulated meanings into themes (Colaizzi, 1978). These themes are common to all the descriptions of the participants about their experience of educational leadership practices. Table 4 presents the result of the analysis of themes from sample statements and meanings.

Table 4. Organization of themes from sample statements and meanings

\begin{tabular}{|c|c|c|}
\hline Statement & Meaning & Theme \\
\hline $\begin{array}{l}\text { We scheduled a meeting with the } \\
\text { teachers and parents to express the issue } \\
\text { on which learning modality, and we } \\
\text { have come up with agreement about it. }\end{array}$ & $\begin{array}{l}\text { The teachers and } \\
\text { parents are consulted } \\
\text { and heard on } \\
\text { important issues. }\end{array}$ & \multirow[t]{3}{*}{$\begin{array}{l}\text { Navigating the } \\
\text { crisis with } \\
\text { adaptive } \\
\text { leadership }\end{array}$} \\
\hline $\begin{array}{l}\text { We create a team by village. There are } \\
\text { assigned volunteers to help those } \\
\text { learners and parents who are not capable } \\
\text { to follow the self-learning modules. }\end{array}$ & $\begin{array}{l}\text { The school principal } \\
\text { and teachers } \\
\text { collaborate in } \\
\text { accomplishing tasks. }\end{array}$ & \\
\hline $\begin{array}{l}\text { I also encourage teachers to really give } \\
\text { their best commitment to deliver } \\
\text { instruction to the most important client } \\
\text { in the department in the new normal. }\end{array}$ & $\begin{array}{l}\text { The school principal } \\
\text { motivates the } \\
\text { teachers to do their } \\
\text { best in their duties. }\end{array}$ & \\
\hline $\begin{array}{l}\text { I manage concerns and issues nowadays } \\
\text { mostly on the implementation of the } \\
\text { basic education learning continuity plan } \\
\text { at the school level specifically the } \\
\text { modular distance learning modality. }\end{array}$ & $\begin{array}{l}\text { The school principal } \\
\text { ensures that learning } \\
\text { continuity plan is } \\
\text { carried out amid the } \\
\text { crisis. }\end{array}$ & $\begin{array}{l}\text { Cultivating } \\
\text { practices in } \\
\text { crisis } \\
\text { management }\end{array}$ \\
\hline
\end{tabular}




\begin{tabular}{|c|c|c|}
\hline $\begin{array}{l}\text { There is a provision of hand sanitation } \\
\text { and advocacy materials. There are items } \\
\text { in the monthly cash program intended } \\
\text { for this. }\end{array}$ & $\begin{array}{l}\text { Materials related to } \\
\text { crisis safety are } \\
\text { allocated budget. }\end{array}$ & \\
\hline $\begin{array}{l}\text { I try hard to balance the timeliness of } \\
\text { target outputs and the increasing virtual } \\
\text { school leadership auxiliary extended } \\
\text { tasks which are not identified in the } \\
\text { national school calendar year of } \\
\text { activities. }\end{array}$ & $\begin{array}{l}\text { The school principal } \\
\text { balances new } \\
\text { demands and tasks } \\
\text { arising from the } \\
\text { crisis. }\end{array}$ & \\
\hline $\begin{array}{l}\text { We created group chats, and we have a } \\
\text { meeting or conference via Google and } \\
\text { Zoom. With these platforms, we are } \\
\text { able to meet the tasks. }\end{array}$ & $\begin{array}{lr}\text { School } & \text { planning } \\
\text { activities } & \text { are } \\
\text { conducted } & \text { and } \\
\text { accomplished online. } & \\
\end{array}$ & \multirow[t]{3}{*}{$\begin{array}{l}\text { Managing } \\
\text { through the } \\
\text { machine }\end{array}$} \\
\hline $\begin{array}{l}\text { My use of digital tools in school } \\
\text { management has increased } \\
\text { dramatically. I do attendance } \\
\text { management, data gathering, reporting, } \\
\text { feedback, and communication online. }\end{array}$ & $\begin{array}{l}\text { Digital tools are used } \\
\text { to perform } \\
\text { management } \\
\text { functions. }\end{array}$ & \\
\hline $\begin{array}{l}\text { I have learned better online ways and } \\
\text { means to present a school report and } \\
\text { communicate with those at the higher } \\
\text { authorities. }\end{array}$ & $\begin{array}{lr}\text { School } & \text { monitoring } \\
\text { and } & \text { evaluation } \\
\text { activities } & \text { are } \\
\text { conducted online. }\end{array}$ & \\
\hline $\begin{array}{l}\text { There are policies that were being } \\
\text { considered because easing its } \\
\text { implementation will make the process } \\
\text { efficient in this time. For example, the } \\
\text { protocol in financial flow. }\end{array}$ & $\begin{array}{l}\text { The processes in the } \\
\text { implementation of } \\
\text { policies are } \\
\text { modified. }\end{array}$ & \multirow[t]{3}{*}{$\begin{array}{l}\text { Freezing the } \\
\text { standards and } \\
\text { patterns }\end{array}$} \\
\hline $\begin{array}{l}\text { I would allow some of my teachers to go } \\
\text { home early, especially those of them } \\
\text { who reside far and have to commute to } \\
\text { go home. }\end{array}$ & $\begin{array}{l}\text { Flexibility of work } \\
\text { hours for teachers is } \\
\text { observed. }\end{array}$ & \\
\hline $\begin{array}{l}\text { I meet my teachers and encourage them } \\
\text { to adjust their grading standards. I told }\end{array}$ & $\begin{array}{l}\text { The teachers are } \\
\text { encouraged to adjust }\end{array}$ & \\
\hline
\end{tabular}


Cahapay. The Phenomenon of Leading without Guidebook: Educational Leadership

Practices of Philippine School Principals in Virulent COVID-19 Times

\begin{tabular}{|c|c|c|}
\hline $\begin{array}{l}\text { them that as long as students submit } \\
\text { anything, give them a passing mark. }\end{array}$ & $\begin{array}{l}\text { their } \quad \text { grading } \\
\text { practices. }\end{array}$ & \\
\hline $\begin{array}{l}\text { Those learners whose parents who are } \\
\text { jobless due to the pandemic are } \\
\text { vulnerable. But we encourage them to } \\
\text { enroll because there are no } \\
\text { miscellaneous fees. }\end{array}$ & $\begin{array}{l}\text { Children belonging } \\
\text { to poor families are } \\
\text { encouraged to } \\
\text { continue. }\end{array}$ & \multirow[t]{3}{*}{$\begin{array}{l}\text { Promoting } \\
\text { inclusivity in } \\
\text { the new normal }\end{array}$} \\
\hline $\begin{array}{l}\text { I have asked the teachers to track the } \\
\text { learners who find difficulty in reading } \\
\text { and create a plan to conduct individual } \\
\text { reading sessions. }\end{array}$ & $\begin{array}{l}\text { Children with } \\
\text { difficulties in } \\
\text { learning are assisted } \\
\text { to learn. }\end{array}$ & \\
\hline $\begin{array}{l}\text { Some modules of the learners especially } \\
\text { those located in the far-flung sitios are } \\
\text { being neglected. But with the dedication } \\
\text { of our teachers, at least } 80 \% \text { of the } \\
\text { learners modules are collected and } \\
\text { monitored. }\end{array}$ & $\begin{array}{lrr}\text { Children } & \text { from } \\
\text { remote areas } & \text { are } \\
\text { reached out by } \\
\text { teachers. }\end{array}$ & \\
\hline $\begin{array}{l}\text { The impact of the crisis exposed the } \\
\text { vulnerability of the mind. I am } \\
\text { concerned most of my teachers - their } \\
\text { difficulties, problems, and anxieties } \\
\text { because of their past experiences. }\end{array}$ & $\begin{array}{l}\text { Guarding mental } \\
\text { health is a primary } \\
\text { concern of the school } \\
\text { principal. }\end{array}$ & \multirow[t]{3}{*}{$\begin{array}{l}\text { Caring first for } \\
\text { what is } \\
\text { essential }\end{array}$} \\
\hline $\begin{array}{l}\text { Ensuring that everyone is safe and } \\
\text { sound in the delivery of basic education } \\
\text { is my common concern for my teachers } \\
\text { and our learners. }\end{array}$ & $\begin{array}{l}\text { The school principal } \\
\text { is concerned about } \\
\text { the safety of teachers } \\
\text { and learners. }\end{array}$ & \\
\hline $\begin{array}{l}\text { I realized that because of the crisis, the } \\
\text { most important thing at the moment is } \\
\text { life. Our goal should be to get out alive } \\
\text { of this situation. }\end{array}$ & $\begin{array}{l}\text { The school principal } \\
\text { recognizes that life } \\
\text { should be the priority } \\
\text { during this crisis. }\end{array}$ & \\
\hline
\end{tabular}


The result of the qualitative data analysis generated six themes of educational leadership practices amid the COVID-19 crisis. These themes explicate the phenomenon as 1.) navigating the crisis with adaptive leadership; 2.) cultivating practices in crisis management; 3.) managing through the machine; 4.) freezing the standards and patterns; 5.) promoting inclusivity in the new normal; and 6.) caring first for what is essential. These themes were a result of the careful examination of the qualitative data. The researcher exhaustively performed a repetitive analysis, constantly reviewing the statements and meanings until the final themes were generated in the process.

\section{Description of the phenomenon}

At this point, the researcher integrated all the resulting ideas into an exhaustive description of the phenomenon. As described by Sanders (2014) in her paper, "the exhaustive description was presented as a narrative account and contained all the dimensions of the lived experience" (p. 299), which in this case, refers to the lived experience on educational leadership practices. The researcher discusses the themes, meanings, and statements below:

The study of the lived experience on educational leadership practices amid the COVID-19 crisis revealed a range of concepts arising from the narratives of the school principals.

The theme 'navigating the crisis with adaptive leadership' explicated the leadership style most practiced by the participants in facing in their everyday management functions. They described their experience of leading their schools amid the crisis as being consensual, distributive, motivational, participatory, inclusive, harmonious, and collaborative towards the achievement of their duties. These characteristics depict an adaptive leadership style.

One participant captured the element of this kind of leadership by stating that: "With the collaborative efforts of teachers and stakeholders we accomplish the emergency and needed tasks in the school by using the new normal means and channels" Participant 4. Supporting this notion of adaptive leadership, another participant expressed that: "As an implementing school of 
indigenous people education, blending with the existing culture and practices is a very challenging art of leadership to ensure the sustainability of partnership" (Participant 5.)

With the emergent theme "cultivating practices in crisis management,' the participants further lived out their leadership practices as they responded to the impacts of the crisis. They performed new tasks related to crisis management in the educational context. The school principals experienced incidental learning moments in the process of performing these new tasks.

A participant articulated that: "I manage concerns and issues nowadays mostly on the implementation of the basic education learning continuity plan at the school level specifically the modular distance learning modality" -Participant 1. Another participant elaborated that: "I try hard to balance the timeliness of target outputs and the increasing virtual school leadership auxiliary extended tasks which are not identified in the national school calendar year of activities" (Participant 5).

Furthermore, the theme 'managing through the machine' explored the emerging perspective on educational leadership as integrating technology in the practice. The participants shared an array of applications of technology toward an efficient performance of their leadership functions. As such, the crisis has given them the experience of intensified use of digital tools in school management.

This experience was portrayed by one participant who said that: "The conference via Google or Zoom is found to be easy and safe. Another, though the use of digital tools, the submission of report through email and private message is fast and convenient" Participant 3. Similarly, another participant affirmed that: "My use of digital tools in school management has increased dramatically. I do attendance management, data gathering, reporting, feedback, and communication online" (Participant 1).

As part of the theme of 'freezing the standards and patterns,' the participants defined the phenomenon of educational leadership practices amid the crisis to a radical extent. They seemed to convey a reverse of the idealist notion of educational leadership as a set of standard practices. Within the context of a turbulent 
situation, educational leadership has become an experience of active process of adjustments.

For instance, a participant recalled that: "The login and logout of the school personnel is set at 8:00 AM-12 NN and 1:00 PM-5:00 PM and this is accomplished online. But there are times that teachers could not do it due to internet connection. I had to consider" -Participant 6. Another participant disclosed that: "I meet my teachers and encourage them to adjust their grading standards. I told them that as long as students submit anything, give them a passing mark" (Participant 4).

Moreover, the theme "promoting inclusivity in the new normal' indicated another aspect of educational leadership practices with consideration of the vulnerable segments of education. The participants consistently mentioned that the delivery of education especially to the disadvantaged groups of children is one of their important goals. They asserted leadership as an opportunity to promote inclusive education at all costs.

This practice was stressed by one participant who told that: "We have asked the teachers to track the learners who find difficulty and reading, create a plan to conduct one-on-one reading lessons" Participant 2. The same practice was observed by another participant who imparted that: "Those learners whose parents who are jobless due to the pandemic are vulnerable. But we encourage them to enrol because there are no miscellaneous fees" (Participant 4).

Lastly, the theme 'caring first for what is essential' showed the human side of educational leadership amid uncertain times. The participants commonly expressed concern for the lives of their teachers and learners. This perception suggests a human facet of educational leadership amid the crisis.

A participant related this facet of educational leadership by uttering that: "The impact of the crisis exposed the vulnerability of the mind. I am concerned most of my teachers - their difficulties, problems, and anxieties because of their past experiences" Participant 1. It was also acknowledged by another participant who said that: "I realized that because of the crisis, the most important thing at the moment is life. Our goal should be to get out alive of this situation" (Participant 4). 
Cahapay. The Phenomenon of Leading without Guidebook: Educational Leadership

Practices of Philippine School Principals in Virulent COVID-19 Times

\section{Structure of the phenomenon}

Given the exhaustive description, it should be reduced to a structure. Colaizzi (1978) described this step as a plain statement of the fundamental structure of the phenomenon. Drawing from the descriptions and review of the selected participants, the researcher presents the structure of the phenomenon of educational leadership practices amid COVID-19 as follows:

The phenomenon of educational leadership amid the COVID-19 crisis is an experience fraught with many radical transformations during a virulent period. It is characterized by a leadership style that is adaptive to the situation. It is comprised of an incidental process of learning new skills related to crisis management and integrating technology into the practices. Amid the devastation caused by the crisis, school leadership suspended some old traditions and focused on the greater good. It is lived out by providing an educational environment of inclusivity and guarding the essential aspects of humanity.

\section{Conclusion}

There is a paucity of knowledge on the lived experience of school principals amid the current global emergency. As such, this paper aimed to uncover the essence of educational leadership practices of Filipino K to 12 school principals in the context of the current COVID-19 crisis. This paper underscores six emerging themes of educational leadership practices during a crisis. The experience of educational leadership can be understood as: 1.) navigating the crisis with adaptive leadership; 2 .) cultivating practices in crisis management; 3.) managing through the machine; 4.) freezing the standards and patterns; 5.) promoting inclusivity in the new normal; and 6.) caring first for what is essential. These themes serve as the basis of the description and structure of the phenomenon of leading education amid the COVID-19 crisis. 
Based on the results, the researcher offers points for consideration in practice. This study depicted how educational leadership has been transformed to an extent that is largely different from the 'old normal' leadership. Rather than view this impression as a negative one, it indicates the dynamism of educational leadership as a practice. As such, there is a need for scholars to reconsider educational leadership preparation programs to be relevant to the current situation. Specifically, it should emphasize the development of essential skills related to adaptive leadership, crisis management, and technology integration. Furthermore, this paper showed educational leadership practices breaking the customs of the old times. There is an emerging trend of leadership practices becoming more humanitarian than ever. It is suggested for practitioners in the field to reflect upon these leadership practices by easing idealisms as needed, fostering inclusive education, and placing a priority on human needs.

While this paper provides several insights about educational leadership practices within the crisis context, some restrictions should be noted. This research is set in a single context and small sample. Thus, the results cannot be used to generalize educational leadership practices in other contexts. The results were also drawn from online interview procedures. It would have been more comprehensive if the process was conducted onsite to complement the results with data from observations and documents.

\section{Reference}

Ashworth, P. D., \& Hagan, M. T. (1993). The meaning of incontinence: A qualitative study of non-geriatric urinary incontinence sufferers. Diary of Advanced Nursing, 18, 1415-1423. https://doi.org/10.1046/j.1365-2648.1993.18091415.x.

Cahapay, M. B. (2020). Stranded College Students amid Corona Virus Disease 2019 Pandemic: An Existential Phenomenology. Journal of Loss and Trauma, 25(6-7), 598-604. https://doi.org/10.1080/15325024.2020.1770955

Cahapay, M. B. (2021). Involvement of Parents in Remote Learning of Children amid COVID-19 Crisis in the Philippines: A Transcendental 
Cahapay. The Phenomenon of Leading without Guidebook: Educational Leadership

Practices of Philippine School Principals in Virulent COVID-19 Times

Phenomenology. International Journal of Sociology of Education, 10(2), 171-192. http://doi.org/10.17583/rise.2021.7317

Colaizzi, P. (1978). Psychological research as a phenomenologist views it. In: Valle, R. S. \& King, M. (1978). Existential Phenomenological Alternatives for Psychology. Open University Press: New York.

Creswell, J. W. (2007). Qualitative inquiry \& research design: Choosing among five approaches (2nd ed.). Sage.

Department of Education (2020). DepEd Basic Education Learning Continuity Plan in the time of COVID-19. Retrieved from https://www.teacherph.com/download-deped-basic-educationlearning-continuity-plan-in-the-time-of-covid-19/

Euber, J. (2020). Telling the real story of the 2020 pandemic and its effects: It's up to you. New York Times. Retrieved from https://nonprofitquarterly.org/telling-the-real-story-of-the-2020pandemic-and-its-effects-its-up-to-you/

Fink, S. (2002). Crisis Management: Planning for the Inevitable. Lincoln, NE: Universe Inc.

Harris, A. (2020). Leading a school during lockdown. My College. Retrieved from https://my.chartered.college/2020/04/leading-a-school-duringlockdown

Harris, A., \& Jones, M. (2012). COVID 19 - school leadership in disruptive times. School Leadership \& Management, 40(4), 243-247. https://doi.org/10.1080/13632434.2020.1811479

Henaku, E. A. (2020). COVID-19 online learning experience of college students: The case of Ghana. International Journal of Multidisciplinary Sciences and Advanced Technology, 1(2), 54-62.

Joshi, A., Vinay, M., \& Bhaskar, P. (2020). Impact of coronavirus pandemic on the Indian education sector: perspectives of teachers on online teaching and assessments. Interactive Technology and Smart Education. https://doi.org/10.1108/itse-06-2020-0087

Karakaya, F., Selçuk, A. R. I. K., Cimen, O., \& Yilmaz, M. (2020). Investigation of the views of biology teachers on distance education during the COVID-19 pandemic. Journal of Education in Science Environment and Health, 6(4), 246-258.

Kaul, M., VanGronigen, B. A., \& Simon, N. S. (2020). Calm during crisis: school principal approaches to crisis management during the COVID- 
19 pandemic. CPRE Policy Briefs. Retrieved from https://repository.upenn.edu/cpre_policybriefs/89

Kruse, S. D., Hackmann, D. G., \& Lindle, J. C. (2020). Academic Leadership During a Pandemic: Department Heads Leading with a Focus on Equity. Frontiers in Education, 5, 614641. https://doi.org/10.3389/feduc.2020.614641

Lin, C. S. (2017). Revealing the "essence" of things: Using phenomenology in LIS research. Qualitative and quantitative methods in libraries, 2(4), 469-478.

Marshall, J., Roache, D., \& Moody-Marshall, R. (2020). Crisis leadership: A critical examination of educational leadership in higher education in the midst of the COVID-19 pandemic. CCEAM, 30.

Morrow, R., Rodriguez, A. and King, N. (2015). Colaizzi's descriptive phenomenological method. The Psychologist, 28(8), 643-644.

Morse, J. M. (1994). Designing funded qualitative research. In Denizin, N. K. \& Lincoln, Y. S., Handbook of qualitative research (2nd $\mathrm{Ed}$ ). Thousand Oaks, CA: Sage.

Moser, A., \& Korstjens, I. (2018). Series: Practical guidance to qualitative research. Part 3: Sampling, data collection and analysis. European Journal of General Practice, 24(1), 9-18. https://doi.org/10.1080/13814788.2017.1375091

Patton, M. Q. (2001). Qualitative research and evaluation and methods (3rd ed.). Beverly Hills, CA Sage.

Rahiem, M. D. (2020). The emergency remote learning experience of university students in Indonesia amidst the COVID-19 crisis. International Journal of Learning, Teaching and Educational Research, 19(6), 1-26. https://doi.org/10.26803/ijlter.19.6.1

Said, F., Ali, I., \& Javed, T. (2021). An Interpretative Phenomenological Analysis of Challenges Faced by the University Teachers in Pakistan Amid Covid-19. International Journal of Educational Research and Innovation, (15), 260-272.

Salmons J. (2015). Qualitative online interviews. Sage

Sanders, C. (2003). Application of Colaizzi's method: Interpretation of an auditable decision trail by a novice researcher. Contemporary Nurse, 14(3), 292-302. https://doi.org/10.5172/conu.14.3.292 
Cahapay. The Phenomenon of Leading without Guidebook: Educational Leadership Practices of Philippine School Principals in Virulent COVID-19 Times

The Lancet (2020). Research and higher education in the time of COVID-19. The Lancet, 396(10251), 583. https://doi.org/10.1016/s01406736(20)31818-3

UNESCO (2020). Supporting teachers in back-to-school efforts: A toolkit for school leaders. Retrieved from https://en.unesco.org/news/supporting-teachers-back-school-effortsafter-covid-19-closures-toolkit-school-leaders

Wirihana, L., Welch, A., Williamson, M., Christensen, M., Bakon, S., \& Craft, J. (2018). Using Colaizzi's method of data analysis to explore the experiences of nurse academics teaching on satellite campuses. Nurse Researcher, 25(4), 30-34. https://doi.org/10.7748/nr.2018.e1516

Michael B. Cahapay holds an Assistant Professor IV rank at Mindanao State University, General Santos City. He is completing his Doctor of Philosophy in Education major in Curriculum Studies at the University of the Philippines, Diliman. His professional interests include pure research and applied research in modeling curriculum phenomenon across educational contexts.

Contact Address: Fatima, General Santos City, 9500 South Cotabato, Philippines.

E-mail: mbcahapay@up.edu.ph 